\title{
CORROSIVE - MECHANICAL DAMAGE OF THE PRESSURE PARTS OF HEAT ENERGY EQUIPMENT
}

\author{
${ }^{1}$ Mária HAGAROVÁ, ${ }^{2}$ Dagmar JAKUBÉCZYOVÁ, 'Tabriela BARANOVÁ \\ ${ }^{1}$ Technical university of Košice, Faculty of Materials, Metallurgy and Recycling, Košice, Slovak Republic, EU, \\ maria.hagarova@tuke.sk, gabriela.baranova@tuke.sk \\ 2 Slovak Academy of Sciences, Institute of Materials Research, Košice, Slovak Republic, EU, \\ jakubeczyova@gmail.com
}

https://doi.org/10.37904/metal.2020.3547

\begin{abstract}
Corrosion - mechanical damage of the economizer pipe of the biomass boiler was analysed. Macroscopic, microscopic and SEM-EDX analysis were used for the analysis of steel samples. The results of the analyses showed a strong degradation effect of a high, up to $30 \%$ solids fraction in the flowing flue gas on the surface of the heat exchange tubes. The high amount of aggressive components, in particular $\mathrm{Cl}, \mathrm{S}, \mathrm{Na}, \mathrm{K}$ and $\mathrm{Zn}$, resulted in the formation of highly aggressive condensate on the tube surface when the operating temperature dropped below $200^{\circ} \mathrm{C}$. The result was a more than $80 \%$ reduction in the wall thickness of the tube at the bottom of its arc, leading to perforation of the economizer tube wall. Spilled heated water released a protective corrosion layer from the surface and exposed the active steel surface. The solution of the unfavourable corrosion - mechanical process is to ensure the required technological parameters (operating temperature and pressure of the flowing medium), chemical composition of the flue gas while ensuring sufficient operational capability and material life of the pressure parts of the heat equipment.
\end{abstract}

Keywords: Heater, high temperature corrosion, abrasion, flue gas

\section{INTRODUCTION}

The share of renewable energy sources to meet global energy demand should rise by a fifth in the next five years to reach $12.4 \%$ of the total energy produced in 2023 . Renewable energy sources will have the fastest growth in the electricity sector, while the projected share in this sector in 2023 is almost $30 \%$ of total energy demand. During this period, renewable energy sources are expected to account for more than $70 \%$ of the world's growth in electricity generation. While they will grow more slowly in the energy sector, in the area of heat management, which includes heating of buildings or industrial plants, they will account for the largest overall share of the demand for this type of energy in 2023. The growth trend of renewable energy sources is shown in (Figure 1) [1]. Consumption of renewable heat sources is expected to increase by $20 \%$ to reach $12 \%$ of demand in the heating sector by 2023. This assumption was also due to the trend of strong growth in energy and heat consumption as a result of economic and population growth. Biomass is also a renewable energy source. The term 'biomass' refers to organic matter that can be converted into energy. Some of the most common fuels for biomass energy systems are wood, agricultural residues and crops grown specifically for energy production. This involves replacing part of the coal with biomass in the boiler plant of the power plant, which is one of the least expensive options for renewable energy [2 -4].

The disadvantage of plant biomass is the high content of chlorine and sulphur (above $0.1 \%$ ) in the fuel, which can be manifested by high-temperature corrosion of heat-exchange surfaces. Therefore, energy boilers for biomass combustion have so far been designed to discharge steam temperatures of $400^{\circ} \mathrm{C}$, respectively $450^{\circ} \mathrm{C}$. The results of the experimental program [5] showed that surface corrosion was observed in low-alloy 
steels at $550^{\circ} \mathrm{C}$ in the wood chip combustion environment, on the austenitic steels oxygen penetration along the grain boundaries and the formation of oxides within the structure. The corrosion effects of flue gases on metal parts of boilers have been analysed in detail $[5,6]$.

During the biomass combustion process, the chlorine present is converted to hydrogen chloride gas, the metal chlorides present in the ash and the eutectic melts of $\mathrm{KCl}-\mathrm{ZnCl}_{2}$. This conversion process can accelerate high temperature corrosion of boiler surfaces, particularly superheater tubes, and significantly affect equipment efficiency by causing unplanned shutdowns or preventively forcing operators to limit steam temperature.

Corrosion of steels in the gaseous environment of chlorides occurs [7]:

- formation of $\mathrm{Cl}_{2}$ from $\mathrm{HCl}$ according to the reaction

$2 \mathrm{HCl}_{(g)}+1 / 2 \mathrm{O}_{2} \rightarrow \mathrm{H}_{2} \mathrm{O}+\mathrm{Cl}_{2}$

- by penetrating $\mathrm{Cl}_{2}$ through the oxide layer and reacting at the oxide-steel interface

$\mathrm{Fe}+\mathrm{Cl}_{2} \rightarrow \mathrm{FeCl}_{2}$

- by evaporating the chlorides according to the reaction

$\mathrm{FeCl}_{2(s)} \rightarrow \mathrm{FeCl}_{2(g)}$

- $\quad$ and oxidation of chlorides

$2 \mathrm{FeCl}_{2(\mathrm{~g})}+3 / 2 \mathrm{O}_{2} \rightarrow \mathrm{Fe}_{2} \mathrm{O}_{3}+\mathrm{Cl}_{2}$

to a crystalline but porous multilayer oxide layer without metal surface protective capability.

The resulting $\mathrm{Cl}_{2}$ acts as a catalyst for the corrosion reaction and prevents the formation of an adhesive corrosion layer. It is able to diffuse inwardly the structure of the steel tubes of the heat equipment along the grain boundaries of the structural components. The corrosion course is very intense, and the rate of corrosion can be described by the linear growth of the corrosion layer.

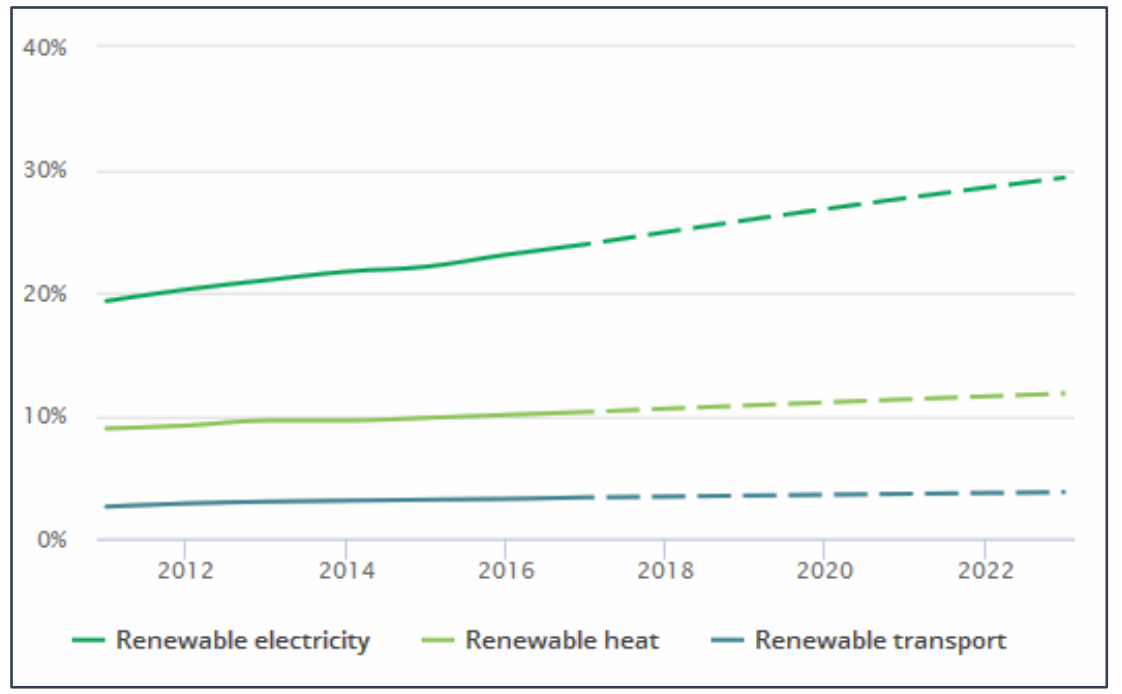

Figure 1 Share of renewable energy sources by industry [1]

The low-melting eutectics formed on the outer surface of the heat exchange tube walls are an essential degradation component. They exist in the form of $\mathrm{NaCl}-\mathrm{FeCl}_{2}$, respectively. $\mathrm{KCl}-\mathrm{FeCl}_{2}$ and have a melting point (eutectic temperature) of $437^{\circ} \mathrm{C}$, respectively $457^{\circ} \mathrm{C}$. In such a liquid form, they prevent the formation of a compact protective layer of corrosion products and at the same time constitute a precondition for the course of electrochemical corrosion, since the liquid phase is in fact an electrolyte. 
Another degradation component of the flue gas is $\mathrm{SO}_{2}$. Sulphur oxide reacts with alkali metal chlorides on the steel surface of heat exchange tubes to form sulphates:

$2 \mathrm{KCl}_{(s)}+\mathrm{SO}_{2}+1 / 2 \mathrm{O}_{2(g)}+\mathrm{H}_{2} \mathrm{O}_{(g)}=\mathrm{K}_{2} \mathrm{SO}_{4(s)}+2 \mathrm{HCl}_{(g)}$

The resulting $\mathrm{HCl}_{(g)}$ can diffuse through the metal / oxide layer, respectively. metal / oxide / deposit to the steel surface and react to form $\mathrm{FeCl}_{2(g)}$. This mechanism is applied in the biomass combustion environment, where alkali metal chlorides dominate in the composition of ash deposits. The sulphates formed are less dangerous to corrosion [8-11].

The paper presents an analysis of corrosion - mechanical damage to the heat exchanger (economizer) of the biomass boiler.

\section{MATERIAL AND EXPERIMENTAL METHODS}

The economizer of the biomass boiler consisted of smooth pipes in interconnected batteries placed in the boiler draft. Pipe dimensions and material: outer diameter $=32.0 \mathrm{~mm}$, wall thickness $=4.5 \mathrm{~mm}$, material - steel $\mathrm{P} 235 \mathrm{GH}$. The flue gas temperature at the inlet to the economizer was about $360^{\circ} \mathrm{C}$ and the outlet temperature was about $180^{\circ} \mathrm{C}$. The feed water temperature in the tubes reached $105^{\circ} \mathrm{C}$. The actual chemical composition of the steel is shown in Table 1 and corresponds to P235GH steel declared by the plant operator.

Table 1 Chemical composition of the P235GH steel

\begin{tabular}{|c|c|c|c|c|c|c|c|c|}
\hline Steel & \multicolumn{8}{|c|}{ Element content in mass \% } \\
\hline & $\mathrm{C}$ & $\mathrm{Mn}$ & $\mathrm{Si}$ & $\mathrm{Cr}$ & $\mathrm{Ni}$ & $\mathrm{Cu}$ & $\mathrm{P}$ & $\mathrm{S}$ \\
\cline { 2 - 10 } \\
$\mathrm{n}$ & 0.16 & 0.42 & 0.21 & 0.17 & 0.19 & 0.14 & 0.03 & 0.03 \\
\hline
\end{tabular}

A view of the location of the economizer tubes in the boiler device is shown in (Figure 2). At the location indicated by the arrow, external wear of the wall surface is visible on the lower pipe bend. Wear, which led to the thinning of the wall of the tube under investigation, was found in several tubes in the economizer. The flue gas stream with high ash content (up to $30 \%$ ) degraded the surface and damaged not only the protective oxide coating but also the steel material itself.

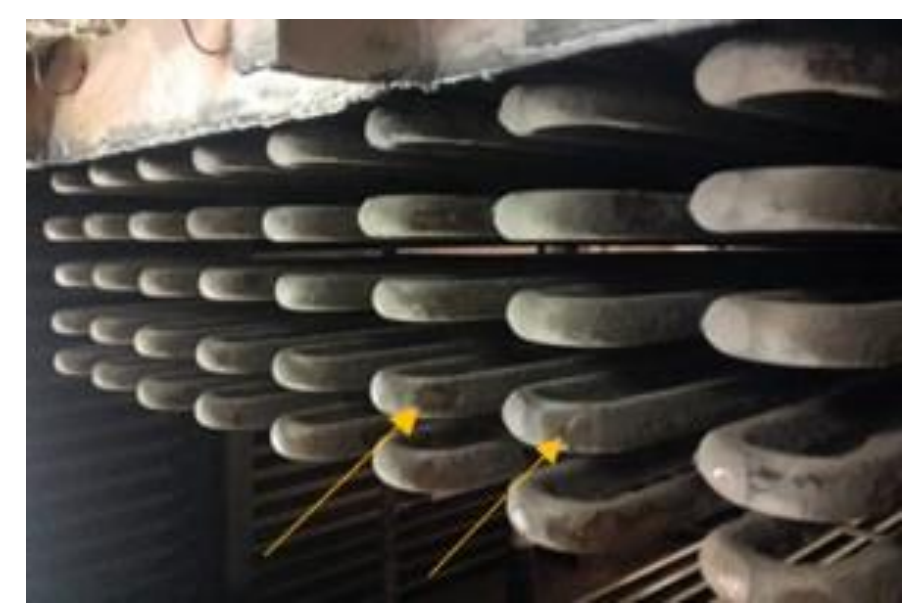

Figure 2 Shot on the bottom of the economizer tubes with visible external wear (indicated by an arrow)

Macroscopic analysis using the LEICA WILD M3Z stereomicroscope was used to determine the causes of corrosion - mechanical damage. Microscopic analysis was performed on an OLYMPUS VANOX-T light 
microscope. Samples were prepared by standard metallographic procedure (grinding, polishing and etching). A JEOL JSM 7000F scanning electron microscope with INCAx_Sight microanalyser was used for EDX analysis of the corrosion layer chemical composition.

\section{RESULTS}

The results of the macroscopic analysis are documented in (Figure 3) and (Figure 4). More detailed view of the damaged location of the lower arc of the tube is in (Figure 3). In (Figure 4) the perforation region of the pipe with cracks on both sides thereof is visible. A cut-out was made at the point of the crack to prepare a sample for microscopic analysis (in Figure 4 this is the location indicated in the formation).

Light microscope observation revealed that the steel structure of the economizer tube was ferritic-pearlitic and is documented in (Figure 5). The steel hardness was $63.8 \mathrm{HV} 10$. On the steel surface on the outside of the pipe wall at the arc location as well as on the crack surface at the edge of the perforation point (the location indicated in Figure 4), there was only a thin corrosion layer that locally reached a depth of max $100 \mu \mathrm{m}$. Samples were taken for the EDX analysis on a scanning electron microscope from the locations (indicated in Figure 3) where a corrosion layer of greater thickness was observed, (Figure 6).

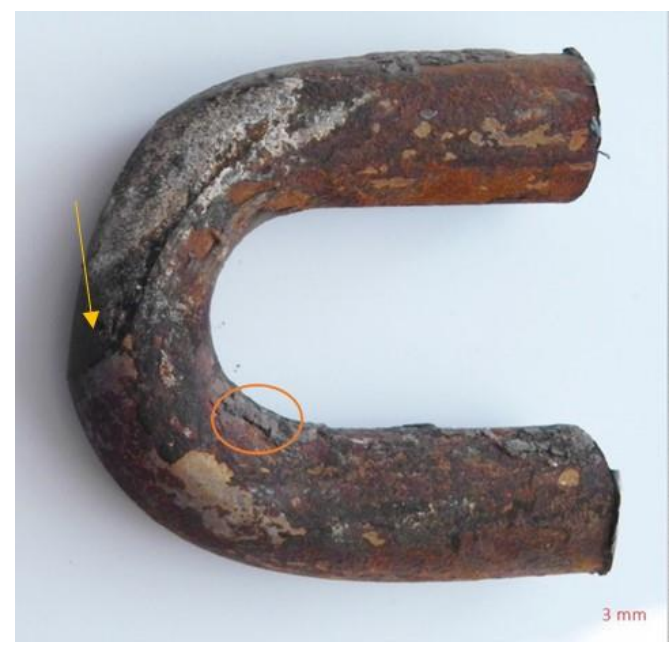

Figure 3 Lower tube bend with a strong abrasive effect of the flue gas

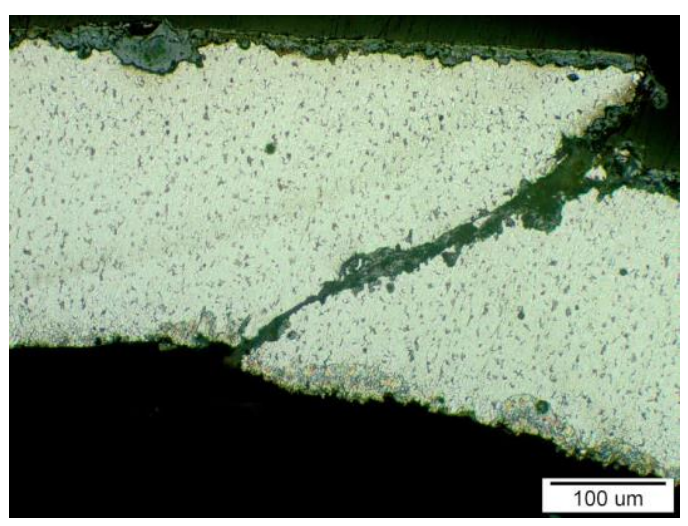

Figure 5 The location of the crack edge documented in (Figure 4)

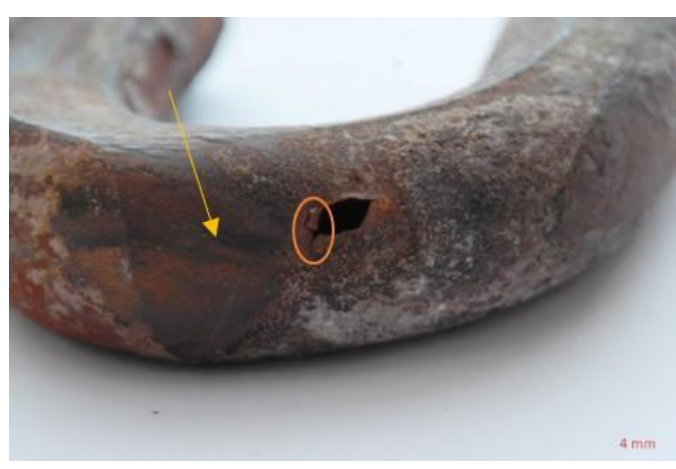

Figure 4 Lower tube bend with wall perforation

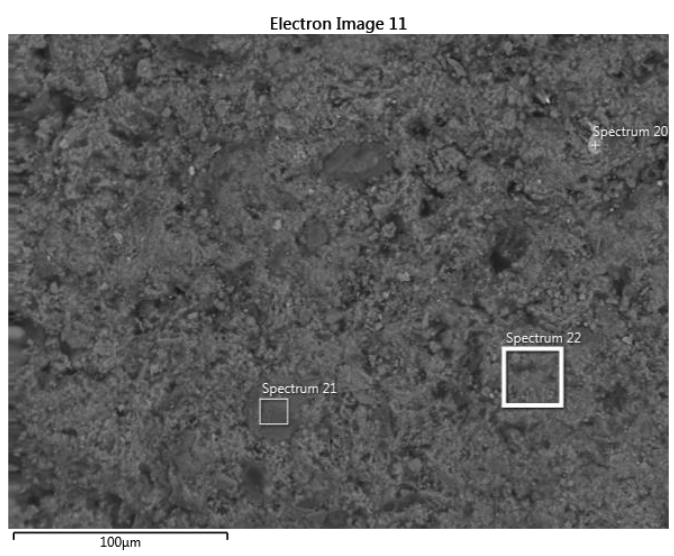

Figure 6 EDX analysis of the corrosion layer on the tube surface from the sampling site of (Figure 3) 


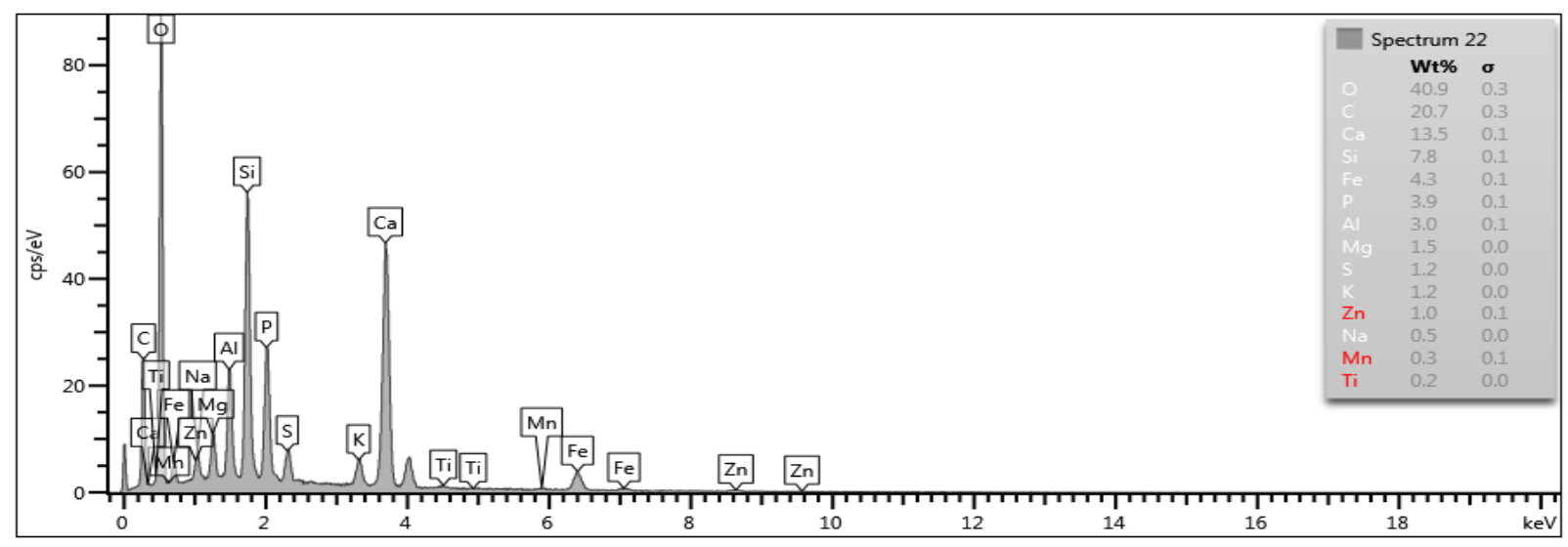

Figure 7 The EDX analysis of the corrosion layer of (Figure 6) - Spectrum 22

The results of the analysis from a documented location on the tube surface are shown as an example of the selected spectrum in (Figure 7) and summarized in Table 2.

Table 2 Results of EDX analysis of corrosion layer

\begin{tabular}{|c|c|c|c|c|c|c|c|}
\hline Element & $\begin{array}{c}\text { Spectrum } \\
\mathbf{2 0} \\
\mathbf{( w t} \%)\end{array}$ & $\begin{array}{c}\text { Spectrum } \\
\mathbf{2 1} \\
\mathbf{( w t} \%)\end{array}$ & $\begin{array}{c}\text { Spectrum } \\
\mathbf{2 2} \\
\mathbf{( w t} \%)\end{array}$ & Element & $\begin{array}{c}\text { Spectrum } \\
\mathbf{2 0} \\
\mathbf{( w t} \%)\end{array}$ & $\begin{array}{c}\text { Spectrum } \\
\mathbf{2 1} \\
\mathbf{( w t} \%)\end{array}$ & $\begin{array}{c}\text { Spectrum } \\
\mathbf{2 2} \\
\mathbf{( w t} \%)\end{array}$ \\
\hline $\mathbf{C}$ & 3.9 & 11.7 & 20.7 & $\mathbf{K}$ & - & 0.3 & 1.2 \\
\hline $\mathbf{O}$ & 23.5 & 48.9 & 40.9 & $\mathbf{C a}$ & 1.2 & 1.3 & 13.6 \\
\hline $\mathbf{M g}$ & - & 36.2 & 1.5 & $\mathbf{M n}$ & 0.8 & - & 0.3 \\
\hline $\mathbf{A l}$ & 0.4 & - & 3.0 & $\mathbf{F e}$ & 68.8 & 0.6 & 4.3 \\
\hline $\mathbf{S i}$ & 0.9 & - & 7.8 & $\mathbf{Z n}$ & - & - & 0.9 \\
\hline $\mathbf{P}$ & 0.2 & - & 3.9 & $\mathbf{C r}$ & 0.2 & - & 0.2 \\
\hline $\mathbf{S}$ & 0,2 & 0.7 & 1.2 & $\mathbf{T i}$ & - & 0.2 & - \\
\hline
\end{tabular}

\section{DISCUSSION}

Macroscopic analysis of economizer tubes (EKO) showed significant corrosion - erosive damage on the steel surface at the bottom of the arc. This damage was caused by a flue gas stream containing a high to $30 \%$ solids content of fly ash. This damage process resulted in a significant loss of pipe wall thickness by the flow of solid ash components in the flue gas. At the thinnest point of the wall of the tube, the thickness was reduced from $4 \mathrm{~mm}$ to $0.7 \mathrm{~mm}$, which represented an $80 \%$ reduction in material. At the point where the pipe wall thickness reached a critical value, the pipe wall was perforated and heated water leaked out. When the water flows from the inside of the pipe towards its outer surface, the corrosion layer moisture has been increased and released from the pipe surface. The result of this process can be seen in (Figure 3) and (Figure 4) in places where it is very thin, resp. totally missing corrosion layer on the surface (areas are indicated by an arrow).

On the inner surface of the pipe and on straight sections, the corrosion layer had a greater thickness and in places reached more than $1 \mathrm{~mm}$.

Analysis of the chemical composition of the economizer tube material and microscopic analysis showed that P235GH steel was used. The ferritic-pearlitic structure had a perlite content corresponding to approximately $0.2 \%$ of the carbon content of the steel; (Figure 5). The grain distribution and shape of the structural 
components of ferrite and perlite represented the state of the steel material structure after drawing and bending.

On the steel surface on the outside of the pipe wall at the arc point as well as on the crack surface at the edge of the perforation point (the place marked in Figure 4) there was only a thin corrosion layer that locally reached a depth of max. The thickness of the corrosion layer was reduced by a stream of solid ash components in the flue gas. As mentioned, the perforation resulted in a considerable separation of the corrosion layer by escaping hot water from the economizer tube.

Based on EDX analysis from a site of greater corrosion layer thickness (site in the formation shown in Figure 3), in detail in (Figure 6), it was found that the corrosion layer contained elements that were part of the chemical composition of the steel, such as $\mathrm{Si}, \mathrm{Cr}, \mathrm{Ni}, \mathrm{Cu}, \mathrm{Fe}$. Furthermore, there were elements such as $\mathrm{S}, \mathrm{Cl}, \mathrm{Mg}, \mathrm{Ca}, \mathrm{Al}, \mathrm{Zn}, \mathrm{K}$, which were components of the flue gas and, when reacted with the metal surface, passed into the corrosion layer. In particular, elements such as: $\mathrm{Cl}, \mathrm{S}, \mathrm{Na}, \mathrm{K}, \mathrm{Zn}$ were involved in the destruction of the protective layer of iron oxides.

When the operating temperature was lowered below $200^{\circ} \mathrm{C}$ and during the plant shutdown, complex compounds of $\mathrm{NaCl}-\mathrm{FeCl}_{2}$, respectively, were formed. $\mathrm{KCl}-\mathrm{FeCl}_{2}$ on the outer surface of the tubes, which in a significant layer disrupted the compact corrosion protective layer [11].

\section{CONCLUSION}

Based on the findings of the experimental analysis can be concluded:

1) the steel structure was ferritic-pearlitic and corresponded to P235GH low carbon steel after normalization annealing;

2) the reaction of the flue gas environment with the outer surface of the steel pipe material resulted in a corrosion layer whose thickness varied. At the bottom of the tube (on the surface of its lower arch) the layer was the thinnest, and adhered well to the steel surface. Under this layer the steel surface was sufficiently protected; the hole depth did not exceed $100 \mu \mathrm{m}$ below the perforation due to the escaping of heated water from inside the economizer tubes, the corrosion layer separated from the steel tube surface;

3) condensation at a temperature below $200^{\circ} \mathrm{C}$ at reduced operating temperature and during standstill has created favorable conditions for low temperature corrosion degradation by the formation of aggressive $\mathrm{Cl}$-based components;

4) the degradation process was also aided by a flue gas stream with a high, up to $30 \%$ solids ash content,

5 ) the abrasive process by the action of particulate matter in the flue gas reduced the wall thickness of the economizer pipe by up to more than $80 \%$ at the bottom of the bend, resulting in perforation of the pipe wall;

6) the solution is to keep the specified technological parameters: temperature of the combustion process and pressure of the flowing medium in the heat-exchange tubes,

7) another effective solution is to reduce the content of aggressive flue gas components to the recommended limit value, especially the $\mathrm{HCl}$ content. It is recommended to keep the chlorine content of the fuel below $0.06 \%$ [12];

8) it is also recommended to reduce the ash content to a maximum of $7.1 \%$, which is a requirement for quality fuel [13]. At the same time, the ash particles are hygroscopic and help to maintain moisture on the steel surface and thus prolong the corrosion process time.

\section{ACKNOWLEDGEMENTS}

This work was supported by project VEGA 1/0622/19 and VEGA 2/0070/20. 


\section{REFERENCES}

[1] INTERNATIONAL ENERGY AGENCY. Renewables 2018. Market analysis and forecast from 2018 to 2023 [online]. [viewed 2020-02-23]. Available from: https://www.iea.org/renewables2018/.

[2] SALAMEH, Z. Renewable Energy System Design, Academic Press, 2014.

[3] HENDERSON, C. Increasing the Flexibility of Coal-Fired Power Plants CCC/242. London: IEA Clean Coal Centre, 2014.

[4] ZHANG, D. Introduction to advanced and ultra-supercritical fossil fuel power plants. In: ZHANG, D. eds. Ultrasupercritical coal power plants, Cambridge: Woodhead Publishing, 2013, pp. 1-20.

[5] CIZNER, J., HERMANOVÁ, Š. Provozní zkoušky vybraných ocelí a slitin v prostředí spalin biomasy. Technologie a materiály, 2013, vol. 3, pp. 128 - 130. [online]. [viewed 2020-03-10]. Available from: www.allforpower.cz.

[6] VAN LOO, S., KOPPEJAN, J. Handbook of Biomass Combustion Co-firing, Earthscan USA, 2008.

[7] KACZMARCZYK, R., MLONKA-MĘDRALA, A. Chloride corrosion in biomass-fired boilers - Fe-O-Cl system thermodynamic analysis. In 1st International Conference on the Sustainable Energy and Environment Development (SEED 2016). Krakow: E3S Web of Conferences, 2016, vol.10, pp. 1-5.

[8] GRABKE, H.J. Metal dusting. In Materials and Corrosion, 2006, vol. 54, pp. 736-746.

[9] WANG, Y. Characteristics of Corrosion Related to Ash Deposition on Boiler Heating Surface during Cofiring of Coal and Biomass. Journal of Chemistry, 2020, pp. 1-9.

[10] ZHANG, Y., WU, W. Alkali sulfate deposits inducedhot corrosion of iron based alloys at intermediate temperatures. Corrosion Science and Protection Technology, 1992, vol. 4, pp. 250-257.

[11] VIKLUND, P., HJÖRNHEDE, A., HENDERSON, P., STÅLENHEIM, A., PETTERSSON, R. Corrosion of superheater materials in a waste-to-energy plant. Fuel Processing Technology, 2013, vol. 105, pp. 106-112.

[12] JORDAN, A., PIENKOWSKI, C. A new technology for obtaining biomass - derived solid fuel for fluid boilers. Pol. J. Environ. Stud., 2010, vol. 19, no. 3, pp. 485-489.

[13] BHATT, M.S. Effect of Ash in Coal on the Performance of Coal Fired Thermal Power Plants.Part I: Primary Energy Effects. Energy Sources, 2006, vol. 28, pp. 25-41. 